\title{
Adsorption Characteristics and Mechanism of Bisphenol A by Magnetic Biochar
}

\author{
Jinpeng Wang ${ }^{1}$ and Ming Zhang ${ }^{2, *}$ \\ 1 College of Biological and Chemical Engineering, Anhui Polytechnic University, Wuhu 241000, China; \\ wangjinpengv3@126.com \\ 2 School of Architecture and Civil Engineering, Anhui Polytechnic University, Wuhu 241000, China \\ * Correspondence: zhangming@ahpu.edu.cn
}

Received: 15 January 2020; Accepted: 5 February 2020; Published: 8 February 2020

\begin{abstract}
In this paper, biochar (BC) was prepared from discarded grapefruit peel and modified to prepare magnetic biochar (MBC). Physical and chemical properties of $B C$ and $M B C$ were characterized, and the results showed that the type of iron oxide loaded by $\mathrm{MBC}$ was $\gamma-\mathrm{Fe}_{2} \mathrm{O}_{3}$. Compared with $\mathrm{BC}$, $\mathrm{MBC}$ has a larger specific surface area and pore volume, with more oxygen-containing functional groups on the surface. $\mathrm{BC}$ and $\mathrm{MBC}$ were used to adsorb and remove endocrine-disrupting chemical (EDC) bisphenol A (BPA) from simulated wastewater. The results showed that the adsorption kinetics and adsorption isotherm of BPA adsorption by $\mathrm{BC}$ and $\mathrm{MBC}$ were mainly in accordance with the pseudo-second-order kinetics model and the Langmuir model. This indicates that the adsorption of $\mathrm{BPA}$ on $\mathrm{BC}$ and $\mathrm{MBC}$ is mainly a chemically controlled monolayer adsorption. Adsorption thermodynamics show that $\mathrm{BC}$ and MBC adsorption of BPA is a spontaneous exothermic reaction, and lowering the temperature is conducive to the adsorption reaction. The effect of solution $\mathrm{pH}$ on the adsorption of BPA by both was significant. The optimum $\mathrm{pH}$ for $\mathrm{BC}$ and MBC to absorb BPA was 6 and 3 , respectively. The concentration of $\mathrm{Na}^{+}$in the range of $0-0.10 \mathrm{~mol} \cdot \mathrm{L}^{-1}$ can promote the adsorption of BPA to MBC. MBC loaded with $\gamma-\mathrm{Fe}_{2} \mathrm{O}_{3}$ not only has excellent magnetic separation ability, but can also reach about $80 \%$ of the initial adsorption capacity after four cycles of adsorption. By analyzing the adsorption mechanism, it was found that the $\mathrm{H}$-bond and the $\pi-\pi$ electron donor-acceptor interaction (EDA) were the main forces for BC and MBC to adsorb BPA.
\end{abstract}

Keywords: biochar; magnetic biochar; adsorption; bisphenol A; $\gamma-\mathrm{Fe}_{2} \mathrm{O}_{3}$

\section{Introduction}

Bisphenol A (BPA) is an emerging contaminant that is often detected in natural waters at levels of ng. $\mathrm{L}^{-1}$ or ug. $\mathrm{L}^{-1}$, making it a trace organic contaminant. Bisphenol A in natural water can cause damage to the reproductive systems of humans or animals. Therefore, scholars generally classify bisphenol A as endocrine-disrupting chemicals (EDCs) [1]. Exposure to endocrine disruptors such as bisphenol A can harm the body. It not only interferes with the male or female reproductive system, but also causes other functional disorders, such as abnormal reproductive function, infertility, precocity, and so on. Affecting the secretion of hormones can also lead to thyroid dysfunction and obesity, which are metabolic disorders [2]. The damage and dysfunction are life-long. In past reports, bisphenol A has often been detected in phenolic wastewater [3,4]. As a monomer of many synthetic materials, bisphenol A has been widely used in diverse industries. For example, bisphenol A can be used to synthesize epoxy resins, polycarbonate [5], phenolic resins, polyester fibers, food cans, and paint coatings [6]. The Brazilian government has banned the production and sale of plastic bottles containing bisphenol A since January 2012. Due to its high industrial yield, environmental universality, and toxicological effect, 
bisphenol A has been listed as a priority pollutant in water treatment in more and more countries and regions [7].

Bisphenol A in the environment can be released into the water body through the polycarbonate plastic's natural degradation [8]. Bisphenol A in plastic products can hydrolyze and contaminate groundwater through landfill leachate [9]. The half-life of bisphenol A in the environment is around $4.5 \mathrm{~d}$ [10], mainly through the biodegradation of bacteria removal [11]. Studies have shown that due to the anaerobic or hypoxic state of water, the degradation of bisphenol A in natural water is slow, or does not even occur [12]. Therefore, the concentration of bisphenol A in surface water fluctuates greatly depending on the region and discharge time [13]. Coagulation, flocculation, precipitation, and other separation methods have been used to remove bisphenol A from water, while traditional biological treatment methods, such as activated sludge, constructed wetlands, and biological filter, have only a limited effect on the removal of bisphenol A $[14,15]$. Some relatively advanced treatment technologies, such as photocatalysis, fenton oxidation, membrane separation, and ozone oxidation, have a good removal effect on bisphenol A [14-18]. However, the above treatment technology also has shortcomings, such as high capital costs (CAPEX) and high operating costs, which limits its application in developing countries. As a water treatment process, adsorption has the characteristics of a good effect, an easy operation, and low cost for bisphenol A [19,20]. There have been many studies on endocrine-disrupting chemicals (EDCs) of carbon-based materials, such as activated carbon [21-23], carbon black, carbon nanotubes [24,25], and biochar [26,27]. Biochar is a low-cost adsorbent that can effectively remove many hydrophilic and hydrophobic organic pollutants [28,29]. At the same time, after pyrolysis or elution, biochar can be used again to absorb pollutants in water; hence, it has a great application value. However, the small size of biochar particles makes it difficult to recover and regenerate biochar after adsorption, which limits its recycling ability [30].

To solve the problem that biochar is difficult to recover after the adsorption of pollutants, some scholars proposed that biochar with magnetic properties can be prepared by chemical methods. While improving the adsorption performance of biochar, saturated adsorption biochar can be quickly recovered from water by a simple external magnetic field [31]. Grapefruit peel is a kind of porous biomass rich in cellulose and pectin [32]. The annual output of pomelo peel is huge, but only a small amount of pomelo peel is reprocessed into medicine or used as chemical raw materials, and most pomelo peel is treated as agricultural waste, resulting in a great waste of resources and environmental pollution [33]. There are few studies on the adsorption of bisphenol A by magnetic biochar, and its adsorption mechanism has not been elucidated. Therefore, in this study, grapefruit peel waste was used as the carbon source of biochar, and the original biochar was prepared. Magnetic biochar was also prepared by chemical precipitation. The effects of dosage, time, initial bisphenol A concentration, temperature, $\mathrm{pH}$, and ionic strength on the adsorption of bisphenol $\mathrm{A}$ by biochar and magnetic biochar were investigated. The mechanism of adsorption of bisphenol A by biochar and magnetic biochar was discussed in combination with the characterization of the original biochar and magnetic biochar, so as to enrich the research of the adsorption of bisphenol A by biochar and magnetic biochar.

\section{Materials and Methods}

\subsection{Chemicals and Materials}

The bisphenol A (98\% purity) reagent was purchased from the Aladdin pharmaceutical company (Shanghai, China). Its physical and chemical properties are shown in Table $1 . \mathrm{FeSO}_{4} \cdot 7 \mathrm{H}_{2} \mathrm{O}$ and $\mathrm{FeCl}_{3} \cdot 6 \mathrm{H}_{2} \mathrm{O}$ were analytically pure (AR). The experimental water was ultrapure water (UP). In order to prevent potential microbial degradation of bisphenol $\mathrm{A}$, the bisphenol $\mathrm{A}$ solution used in the experiment was prepared before each experiment. 
Table 1. Characteristics of bisphenol A (BPA).

\begin{tabular}{ccccc}
\hline $\begin{array}{c}\text { Molecular } \\
\text { Formula }\end{array}$ & $\begin{array}{c}\text { Molecular } \\
\text { Mass }\end{array}$ & $\mathbf{p K}_{\mathbf{a}}$ & $\begin{array}{c}\text { Lipid-Water Partition } \\
\text { Coefficient (lgP) }\end{array}$ & Chemical Structure \\
$\mathrm{C}_{15} \mathrm{H}_{16} \mathrm{O}_{2}$ & 228.29 & $\mathrm{pK}_{\mathrm{a}}=9.59$ & 3.32 &
\end{tabular}

\subsection{Biochar Preparation and Modification}

The washed and dried grapefruit peel was used as biomass material for pyrolysis at $400{ }^{\circ} \mathrm{C}$ for $2 \mathrm{~h}$. We took out the pomelo peel biochar after pyrolysis, ground it, and passed it through a 60-mesh sieve. The seal prepared biochar was put in a plastic bottle labeled "BC" for later use. We took $5 \mathrm{~g}$ of the prepared pomelo peel biochar, soaked it in $100 \mathrm{~mL}$ of $\mathrm{FeSO}_{4}$ of $0.125 \mathrm{~mol} \cdot \mathrm{L}^{-1}$ and $0.25 \mathrm{~mol} \cdot \mathrm{L}^{-1}$ of $\mathrm{FeCl}_{3}$ solution, and mixed it evenly on the magnetic mixer. Then, we gradually added $100 \mathrm{~mL}$ of $1 \mathrm{~mol} \cdot \mathrm{L}^{-1}$ of $\mathrm{NaOH}$ solution. After the reaction was complete, we continued stirring for $1 \mathrm{~h}$. Then, we separated it with a magnetic field and washed it with ultra-pure water until the $\mathrm{pH}$ of the solution system was close to neutral. After drying and grinding, the seal prepared magnetic biochar was put in a plastic bottle labeled "MBC" for later use.

\subsection{Characterization of $B C$ and $M B C$}

The surface structure and morphology of biochar were observed by scanning electron microscopy (SEM, MLA650F, Hillsboro, OR, USA). The contents of C, O, and Fe were determined by X-ray photoelectron spectroscopy (XPS, ESCALAB250). The surface area of biochar was determined by the Brunauer-Emmett-Teller (BET) adsorption method (ASAP2460, Norcross, GA, USA). The type of iron supported by pomelo peel-based biochar and the surface functional groups of $B C$ and $M B C$ were analyzed by X-ray photoelectron spectroscopy (XPS). The magnetization of the samples was measured at room temperature using a vibrating sample magnetometer (VSM, Lake shore 7410, Westerville, $\mathrm{OH}$, USA). The $\mathrm{pH}$ of biochar was determined as follows: biochar was mixed with ultrapure water at a mass ratio of 1:10, stirred magnetically for $0.5 \mathrm{~h}$, and then placed for $1 \mathrm{~h}$. Then, the $\mathrm{pH}$ of biochar was measured by a PHS-3C pH meter (thunder magnet, Shanghai, China). The zero point charge of biochar was measured by titration in accordance with reference [34].

\subsection{Adsorption Experiments}

A total of $0.01 \mathrm{~g}$ of $\mathrm{BC}, \mathrm{MBC}$, and $25 \mathrm{~mL}$ BPA solution were weighed in a $50 \mathrm{~mL}$ centrifuge tube, placed in a constant temperature oscillator in a water bath, and shaken in the dark at $150 \mathrm{rpm}$ (to avoid possible BPA photodegradation). After a certain period of oscillation, the absorbance of the solution was measured at the wavelength of $276 \mathrm{~nm}$ by UV-visible spectrophotometer (UV-1810, Youke, Shanghai, China) after filtrating the $0.45 \mathrm{um}$ membrane, and the concentration was converted into the established BPA standard curve [35]. In the single-factor experiment, the effects of the biochar dosage $\left(0.1,0.2,0.3,0.4,0.5\right.$, and $\left.0.6 \mathrm{~g} \cdot \mathrm{L}^{-1}, \mathrm{BPA}=2 \mathrm{mg} \cdot \mathrm{L}^{-1}\right)$, adsorption time $(10,20,30,60,90,120,150$, and $\left.180 \mathrm{~min}, \mathrm{BPA}=4 \mathrm{mg} \cdot \mathrm{L}^{-1}\right)$, initial BPA concentration $\left(8,12,18,26,36,50,70,100,150\right.$, and $\left.200 \mathrm{mg} \cdot \mathrm{L}^{-1}\right)$, reaction temperature $\left(25,35\right.$, and $\left.45^{\circ} \mathrm{C}\right), \mathrm{pH}\left(3-10, \mathrm{BPA}=10 \mathrm{mg} \cdot \mathrm{L}^{-1}\right), \mathrm{Na}^{+}$concentration $(0,0.2,0.4$, $0.6,0.8$, and $0.10 \mathrm{~mol} \cdot \mathrm{L}^{-1}, \mathrm{BPA}=20 \mathrm{mg} \cdot \mathrm{L}^{-1}$ ) on the adsorption of bisphenol A by $\mathrm{BC}$ and $\mathrm{MBC}$ were investigated. In order to test the reusability of $\mathrm{MBC}$, adsorption and desorption experiments were designed as follows: $0.0100 \mathrm{~g}$ of MBC was weighed in a $50 \mathrm{~mL}$ centrifuge tube. We added $25 \mathrm{~mL}$, $100 \mathrm{mg} \cdot \mathrm{L}^{-1}$ bisphenol A solution and shook it for $2 \mathrm{~h}$. Then, MBC was separated with a magnet and the concentration of supernatant was determined. The separated biochar was soaked in an appropriate amount of ethanol, washed and dried overnight, and continued to the next adsorption test. 


\subsection{Data Analysis}

The adsorption test was repeated three times for each group, and the mean value of the data was taken. Removal rate $\mathrm{R}(\%)$ and adsorption capacity $Q_{e}\left(\mathrm{mg} \cdot \mathrm{g}^{-1}\right)$ were calculated by the following two formulas:

$$
\begin{gathered}
\mathrm{R}(\%)=\frac{c_{0}-c_{t}}{c_{0}} \times 100, \\
Q e=\left(c_{0}-c_{t}\right) \times \frac{v}{m},
\end{gathered}
$$

where $C_{0}\left(\mathrm{mg} \cdot \mathrm{L}^{-1}\right)$ is the initial concentration of bisphenol A. $C_{t}\left(\mathrm{mg} \cdot \mathrm{L}^{-1}\right)$ is the residual concentration of bisphenol A at time $t . V(\mathrm{~mL})$ is the solution volume. $m(\mathrm{~g})$ is the added mass of biochar.

The fitting model formulas adopted in this experiment are also listed as follows:

Pseudo-first-order kinetic equation:

$$
\ln \left(q_{e}-q_{t}\right)=\ln q_{e}-k_{1} t
$$

pseudo-second-order kinetic equation:

$$
\frac{\mathrm{t}}{q_{t}}=\frac{t}{q_{e}}+\frac{1}{k_{2} q_{e}^{2}}
$$

Elovich equation:

$$
q_{t}=a+b \ln t ; \text { and }
$$

intraparticle diffusion equation:

$$
q_{t}=k_{3} t^{\frac{1}{2}}+I
$$

where $q_{e}\left(\mathrm{mg} \cdot \mathrm{g}^{-1}\right)$ is the adsorption capacity of bisphenol A at the adsorption equilibrium. $Q_{t}\left(\mathrm{mg} \cdot \mathrm{g}^{-1}\right)$ is the adsorption capacity of bisphenol A at time $t . k_{1}\left(\mathrm{~min}^{-1}\right)$ and $k_{2}\left[\mathrm{~g} \cdot\left(\mathrm{mg}^{-1} \cdot \mathrm{min}\right)^{-1}\right]$ are the adsorption rate constants of pseudo-first- and pseudo-second-order kinetic equations, respectively. $\mathrm{A}\left[\mathrm{mg} \cdot(\mathrm{g} \cdot \mathrm{min})^{-1}\right]$ and $b\left(\mathrm{~g} \cdot \mathrm{mg}^{-1}\right)$ are the initial adsorption rate constants and desorption rate constants, respectively. $k_{3}\left[\mathrm{mg} \cdot\left(\mathrm{mg} \cdot \mathrm{min}^{1 / 2}\right)^{-1}\right]$ is the interparticle diffusion rate constant, which is related to the diffusion coefficient of particles. $I$ is the constant related to the boundary layer thickness. Langmuir equation:

$$
Q_{e}=\frac{Q_{m} K_{L} C_{e}}{1+K_{L} C_{e}}
$$

Freundlich equation:

$$
Q_{e}=K_{F} C_{e}^{\frac{1}{n}}
$$

Temkim equation:

$$
Q_{e}=A \ln \left(K_{T} C_{e}\right) ; \text { and }
$$

Dubinin-Radushkevich(D-R) equation:

$$
Q_{e}=Q_{0} \exp \left\{-0.5\left[\frac{R T \ln \left(1+\frac{1}{C_{e}}\right)^{2}}{E}\right]\right\}
$$

where, $Q_{e}$ is the equilibrium adsorption capacity of bisphenol A $\left(\mathrm{mg} \cdot \mathrm{L}^{-1}\right) . \quad C_{e}$ is the solution concentration $\left(\mathrm{mg} \cdot \mathrm{L}^{-1}\right)$ at adsorption equilibrium. $K_{L}$ is Langmuir isothermal adsorption constant $\left(\mathrm{L} \cdot \mathrm{mg}^{-1}\right) . \quad K_{F}\left(\mathrm{~L} \cdot \mathrm{mg}^{-1}\right)$ and $\mathrm{n}$ are Freundlich equation constants. $Q_{m}$ is the theoretical maximum adsorption capacity $\left(\mathrm{mg} \cdot \mathrm{g}^{-1}\right)$. A is the coefficient of the Temkim equation, which is related to the adsorption heat. $K_{T}$ is the equilibrium binding constant, $\mathrm{mg} \cdot \mathrm{L}^{-1} \cdot Q_{0}$ is the maximum unit adsorption, $\mathrm{mg} \cdot \mathrm{g}^{-1} . R$ is the theoretical gas constant, $8.314 \mathrm{~J} \cdot(\mathrm{mol} \cdot \mathrm{K})^{-1} . T$ is the absolute temperature. $E$ is the adsorption free energy, $\mathrm{J} \cdot \mathrm{mol}^{-1}$. 


\section{Results}

\subsection{Characterization of $B C$ and $M B C$}

Some physical and chemical properties of BC and MBC are shown in Table 2 [36]. Compared with $\mathrm{BC}, \mathrm{MBC}$ showed that the composition of the $\mathrm{C}$ element decreased, while the contents of $\mathrm{O}$ and $\mathrm{Fe}$ increased. This indicates that in addition to loading Fe onto the surface of BC, more oxygen-containing functional groups are also introduced in the modification process. The specific surface area of MBC increased significantly from $1.706 \mathrm{~m}^{2} \cdot \mathrm{g}^{-1}$ to $20.732 \mathrm{~m}^{2} \cdot \mathrm{g}^{-1}$. This may be due to the high specific surface area of the loaded iron oxide nanoparticles, which significantly increases the surface area. The increase of the specific surface area is beneficial to the adsorption capacity of the adsorbent. At the same time, the pore volume and aperture of $\mathrm{MBC}$ are also larger than that of $\mathrm{BC}$, which is more conducive to the adsorption of macromolecules.

Table 2. Physico-chemical characteristics of biochar (BC) and magnetic biochar (MBC).

\begin{tabular}{|c|c|c|c|c|c|c|c|c|}
\hline & $\mathrm{C}(\%)$ & $\mathrm{O}(\%)$ & $\mathrm{Fe}(\%)$ & $\mathrm{pH}$ & $\mathrm{pH}_{\mathrm{pzc}}$ & $\begin{array}{c}\text { Specific } \\
\text { Surface Area } \\
\left(\mathrm{m}^{2} / \mathrm{g}\right)\end{array}$ & $\begin{array}{l}\text { Pore Volume } \\
\qquad\left(\mathrm{cm}^{3} / \mathrm{g}\right)\end{array}$ & $\begin{array}{c}\text { Pore } \\
\text { Diameter } \\
(\mathrm{nm})\end{array}$ \\
\hline BC & 72.32 & 20.02 & 0.43 & 10.13 & 10.98 & 1.706 & 0.003 & 5.896 \\
\hline МBC & 41.57 & 38.11 & 18.05 & 7.96 & 5.86 & 20.732 & 0.110 & 20.897 \\
\hline
\end{tabular}

According to Figure $1 \mathrm{a}, \mathrm{b}$ of the SEM of BC and MBC, it can be seen that the surface of BC is relatively smooth and the pore structure is not completely developed. However, the surface of $\mathrm{MBC}$ is relatively rough, with significantly more pores than $\mathrm{BC}$, and the surface is loaded with many nano-iron oxide particles. To test the magnetic strength of the prepared magnetic biochar, the hysteresis loop of MBC was determined at room temperature $(298.15 \mathrm{~K})$. The results show that the hysteresis loop of $\mathrm{MBC}$ is symmetric about the origin and has obvious superparamagnetism [37]. Its saturation magnetization (Ms) is up to $30.60 \mathrm{emu} \cdot \mathrm{g}^{-1}$. The lower right corner of Figure 1c shows the separation effect of BC and MBC after 1 min of an external magnetic field. It can be found that MBC has excellent magnetic separation ability. Figure $1 \mathrm{~d}$ shows the adsorption of BPA by a MBC cycle for four times. After a cyclic adsorption for four times, the adsorption capacity of bisphenol A by MBC still reached about $80 \%$ of the initial adsorption capacity, indicating that the experimental MBC had a good cyclic adsorption performance. The reason for the adsorption capacity decrease may be that during multiple adsorption-desorption processes, some of the nano-iron oxide particles and active substances on the surface of MBC were eluted, resulting in a decrease of the adsorption capacity. Table 3 shows the adsorption capacity of bisphenol $\mathrm{A}$ and the magnetic strength of the magnetic materials prepared in previous literatures.

Figure 2 shows the XPS analysis spectrum of BC and MBC. It can be found from the XPS spectrum (a) that the biochar before and after modification has a similar XPS peak shape, and the peak at the binding energy of $284.8 \mathrm{eV}$ corresponds to the $\mathrm{C}$ element in $\mathrm{BC}$ and MBC. After modification, the strength peak of the $C$ element in $\mathrm{MBC}$ is weakened, while that of the O element is enhanced. The $C 1 \mathrm{~s}$ spectrum showed that both the surface of $\mathrm{BC}$ and $\mathrm{MBC}$ contained a large number of oxygen-containing functional groups, including $\mathrm{C}-\mathrm{C} / \mathrm{C}=\mathrm{C}, \mathrm{C}-\mathrm{OH}, \mathrm{C}=\mathrm{O} / \mathrm{C}-\mathrm{O}-\mathrm{C}, \mathrm{COOH}$, etc. Compared with $\mathrm{BC}$, the peak area of $\mathrm{C}-\mathrm{C} / \mathrm{C}=\mathrm{C}$ decreases, the peak area of $\mathrm{C}-\mathrm{OH}$ and $\mathrm{C}=\mathrm{O} / \mathrm{C}-\mathrm{O}-\mathrm{C}$ increases, and $\mathrm{COOH}$ appears. This indicates that in the process of magnetic modification, more oxygen-containing functional groups are introduced on the surface of $\mathrm{BC}$. The $\mathrm{O}$ 1s spectrum showed that the $\mathrm{C}$ element in $\mathrm{BC}$ mainly existed in the form of organic carbon (531.75 and $533.02 \mathrm{eV}$ ) [43]. The peak area of $\mathrm{C}-\mathrm{OH}$ and $\mathrm{C}=\mathrm{O} / \mathrm{C}-\mathrm{O}-\mathrm{C}$ of MBC decreased compared with that of $\mathrm{BC}$, while the peak area of Fe-O increased significantly, and the peak of $\mathrm{O}$ element shifted from $531.80 \mathrm{eV}$ to $530.03 \mathrm{eV}$, closer to the Fe-O peak. This indicates that the introduced Fe is not loaded on the surface of BC in the form of hydroxide. In order to determine the phase of iron oxide, the Fe 2 p spectrum of MBC is shown in Figure $2 d$. The two main peaks at 
$710.7 \mathrm{eV}$ and $724.3 \mathrm{eV}$ correspond to $\mathrm{Fe} 2 \mathrm{p}_{3 / 2}$ and $\mathrm{Fe} 2 \mathrm{p}_{1 / 2}$, respectively. The satellite peak at $719.3 \mathrm{eV}$ is the characteristic peak of $\gamma-\mathrm{Fe}_{2} \mathrm{O}_{3}$ [44]. Moreover, the surface of $\mathrm{MBC}$ is slightly red. It indicates that the iron oxide supported on the pomelo peel-based biochar is $\gamma-\mathrm{Fe}_{2} \mathrm{O}_{3}$.

Table 3. Comparison of BPA removal by reported adsorbents in the literature and this study.

\begin{tabular}{cllll}
\hline Adsorbent & \multicolumn{1}{c}{$\begin{array}{c}\text { Experimental } \\
\text { Conditions }\end{array}$} & $\begin{array}{c}\mathbf{Q}_{\mathbf{m a x}} \\
(\mathbf{m g} / \mathbf{g})\end{array}$ & $\mathbf{M}_{\mathbf{s}}(\mathbf{e m u} / \mathbf{g})$ & Reference \\
\hline $\begin{array}{c}\text { Molecularly imprinted } \\
\text { polymers based on } \\
\text { magnetic graphene oxide }\end{array}$ & $\begin{array}{l}500 \mathrm{mg} \cdot \mathrm{L}^{-1} \mathrm{BPA} \\
100 \mathrm{mg} \cdot \mathrm{L}^{-1} \text { adsorbent }\end{array}$ & 106.38 & 6.12 & Wang et al. [38] \\
\hline $\begin{array}{c}\text { Polyethersulfone magnetic } \\
\text { microspheres }\end{array}$ & $\begin{array}{l}68 \mathrm{mg} \cdot \mathrm{L}^{-1} \mathrm{BPA} \\
300 \mathrm{mg} \cdot \mathrm{L}^{-1} \text { adsorbent }\end{array}$ & 63.24 & 17.78 & Yu et al. [39] \\
\hline $\begin{array}{c}\text { Magnetic microbeads } \\
\text { Magnetic }\end{array}$ & $\begin{array}{l}300 \mathrm{mg} \cdot \mathrm{L}^{-1} \mathrm{BPA} \\
100 \mathrm{mg} \cdot \mathrm{L}^{-1} \text { adsorbent }\end{array}$ & 139.6 & $\begin{array}{c}\text { Not } \\
\text { mentioned }\end{array}$ & Osman et al. [40] \\
\hline $\begin{array}{c}\text { CuZnFe } \mathbf{O}_{4} \text {-biochar } \\
200 \mathrm{mg} \cdot \mathrm{L}^{-1} \mathrm{BPA} \text { adsorbent }\end{array}$ & 263.2 & 37.6 & Heo et al. [41] \\
\hline $\begin{array}{c}\text { Magnetic composite } \\
\text { organic sepiolite }\end{array}$ & $\begin{array}{l}50 \mathrm{mg} \cdot \mathrm{L}^{-1} \mathrm{BPA} \\
1000 \mathrm{mg} \cdot \mathrm{L}^{-1} \text { adsorbent }\end{array}$ & 36.30 & 14.1 & Yang et al. [42] \\
\hline $\begin{array}{c}\text { Magnetic grapefruit peel } \\
\text { biochar }\end{array}$ & $\begin{array}{l}200 \mathrm{mg} \cdot \mathrm{L}^{-1} \mathrm{BPA} \\
400 \mathrm{mg} \cdot \mathrm{L}^{-1} \text { adsorbent }\end{array}$ & 229.19 & 30.60 & Our study \\
\hline
\end{tabular}

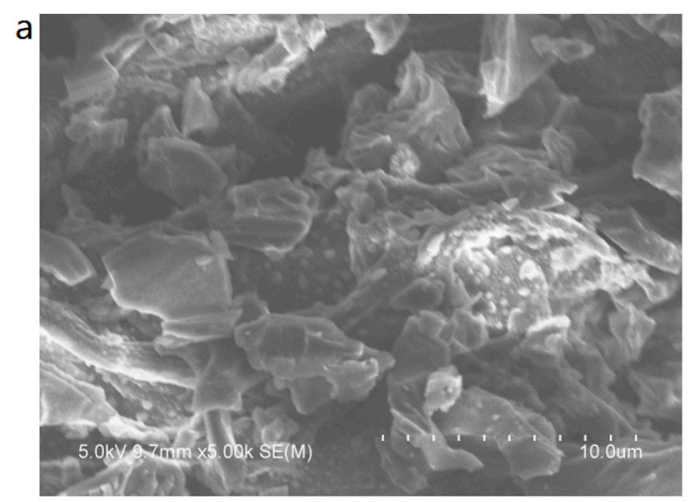

b
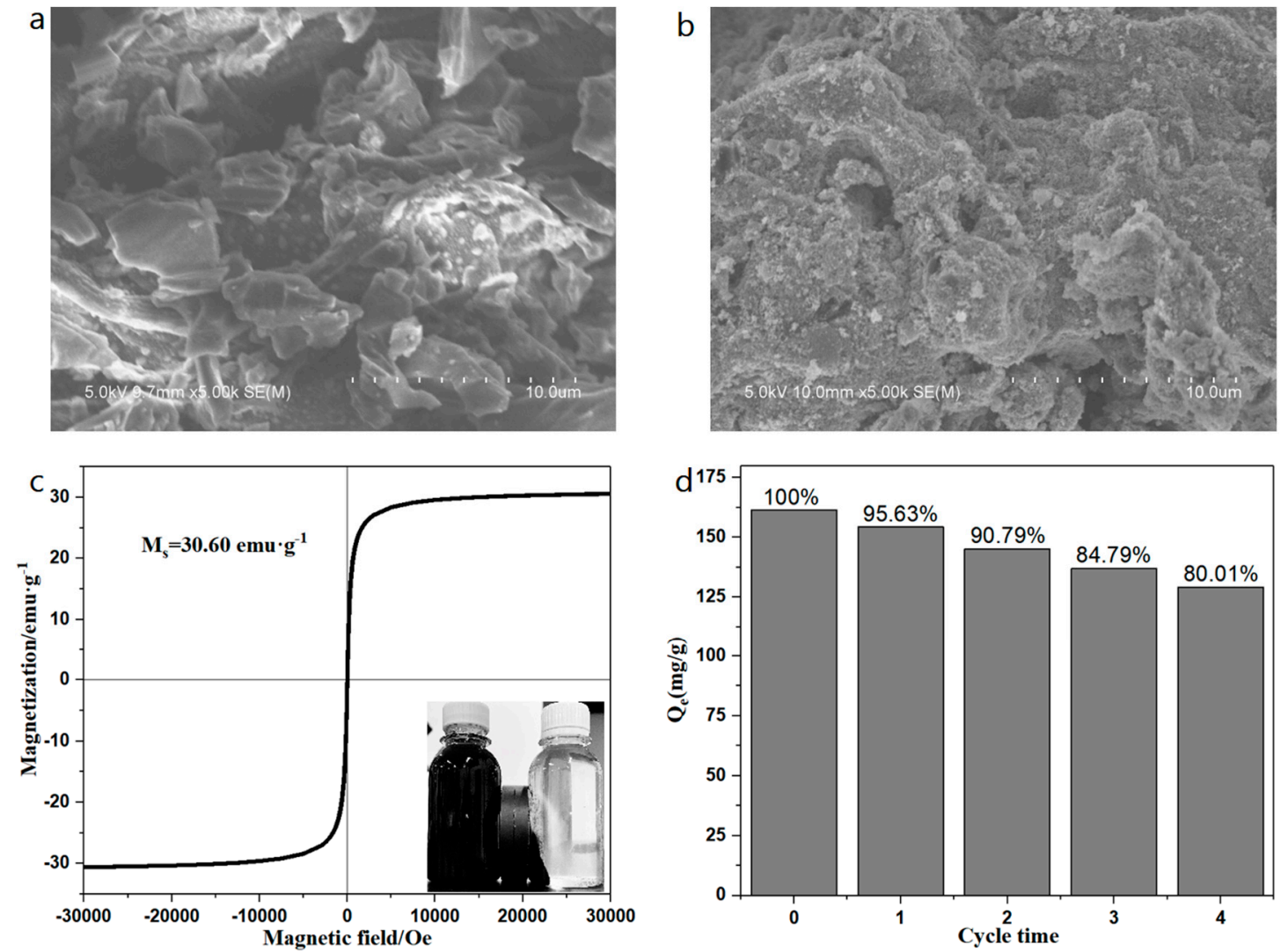

Figure 1. SEM image of BC (a) and $\operatorname{MBC}(\mathbf{b})$, magnetic hysteresis curve of MBC (c), reusability of MBC for BPA removal (d). 

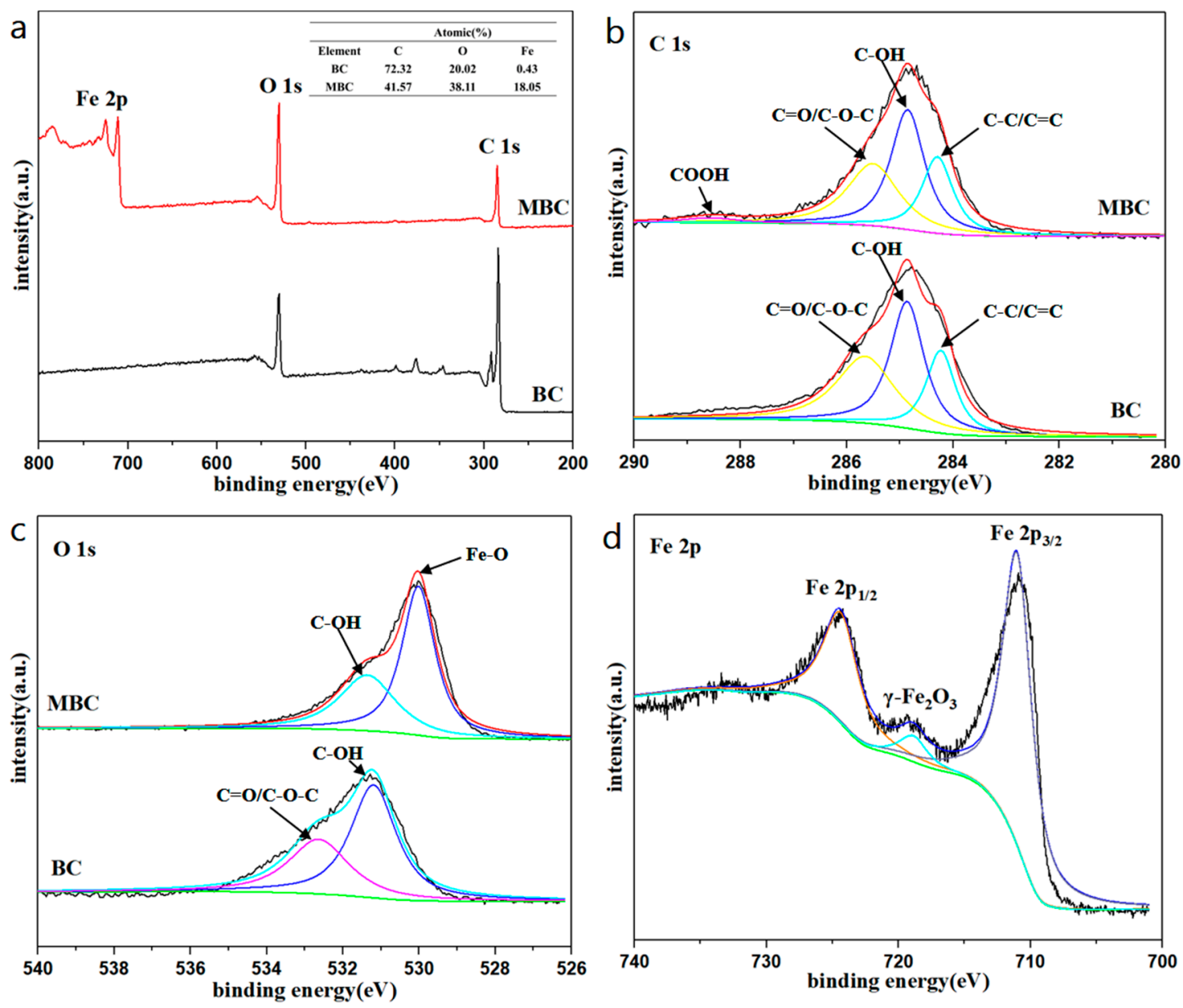

Figure 2. (a) XPS spectra of BC and MBC, and XPS patterns of the (b) C 1s, (c) O 1s, (d) Fe 2p.

\subsection{Effects of Biochar Dosage}

The effect of biochar dosage on the adsorption of bisphenol A by BC and MBC is shown in Figure 3. The removal rate of bisphenol A increased with the increase of the biochar dosage. When the biochar dosage was $0.1 \mathrm{~g} \cdot \mathrm{L}^{-1}$, the removal rates of bisphenol A by BC and $\mathrm{MBC}$ were $50.19 \%$ and $64.13 \%$, respectively. When the biochar dosage increased to $0.4 \mathrm{~g} \cdot \mathrm{L}^{-1}$, the removal rate increased significantly, $88.01 \%$ and $94.74 \%$, respectively. Subsequently, the biochar dosage was increased, and the removal rate remained unchanged. The increased removal rate can be attributed to the increased biochar, which not only increases the effective specific surface area of adsorption, but also increases the active site of adsorption [45]. At the same time, the unit adsorption of bisphenol A by BC and MBC decreased gradually. This is because in the case of limited solutes, too many adsorbents will not only compete for solutes, but also overlap the effective adsorption active sites on the biochar surface [46]. 


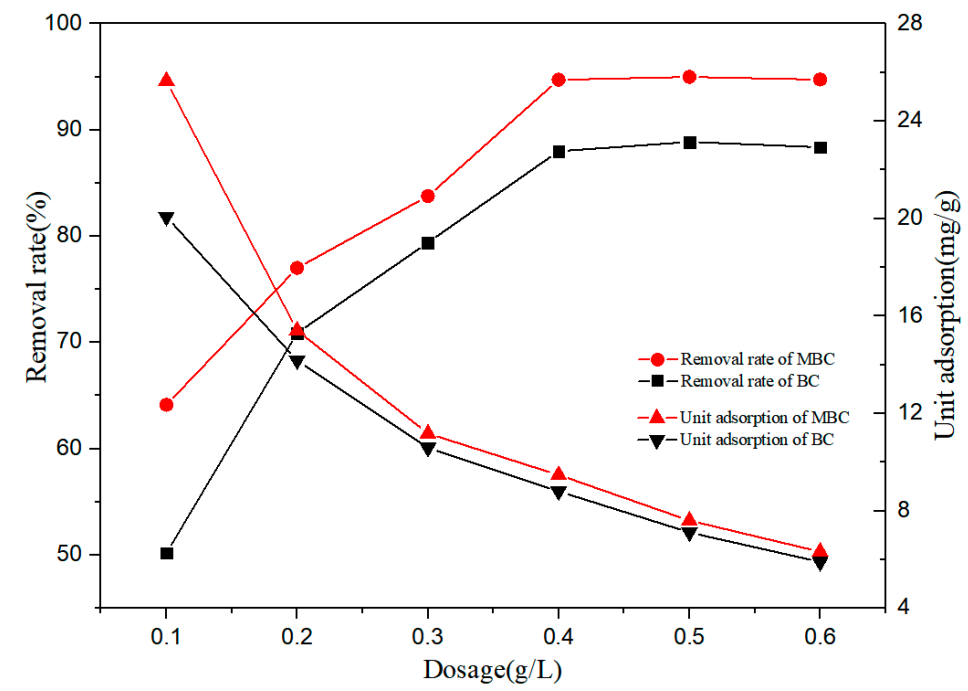

Figure 3. Effects of BC and MBC dosage on BPA adsorption.

\subsection{Effects of Time}

The effect of adsorption time on the adsorption of bisphenol A by BC and MBC is shown in Figure $4 \mathrm{a}$. The adsorption of bisphenol A by the two biochars reached equilibrium at around $150 \mathrm{~min}$. Compared with BC, MBC can reach more than $87 \%\left(8.5420 \mathrm{mg} \cdot \mathrm{g}^{-1}\right)$ of the saturated adsorption capacity $\left(9.7098 \mathrm{mg} \cdot \mathrm{g}^{-1}\right)$ within $30 \mathrm{~min}$ of the initial adsorption stage, which is significantly faster than BC. In order to further explore the adsorption process of bisphenol A by BC and MBC, pseudo-first-order and pseudo-second-order kinetic models, Elovich model, and the intraparticle diffusion model are used to fit the experimental data. The fitting curve is shown in Figure 4, and the parameter fitting results are shown in Table 4.
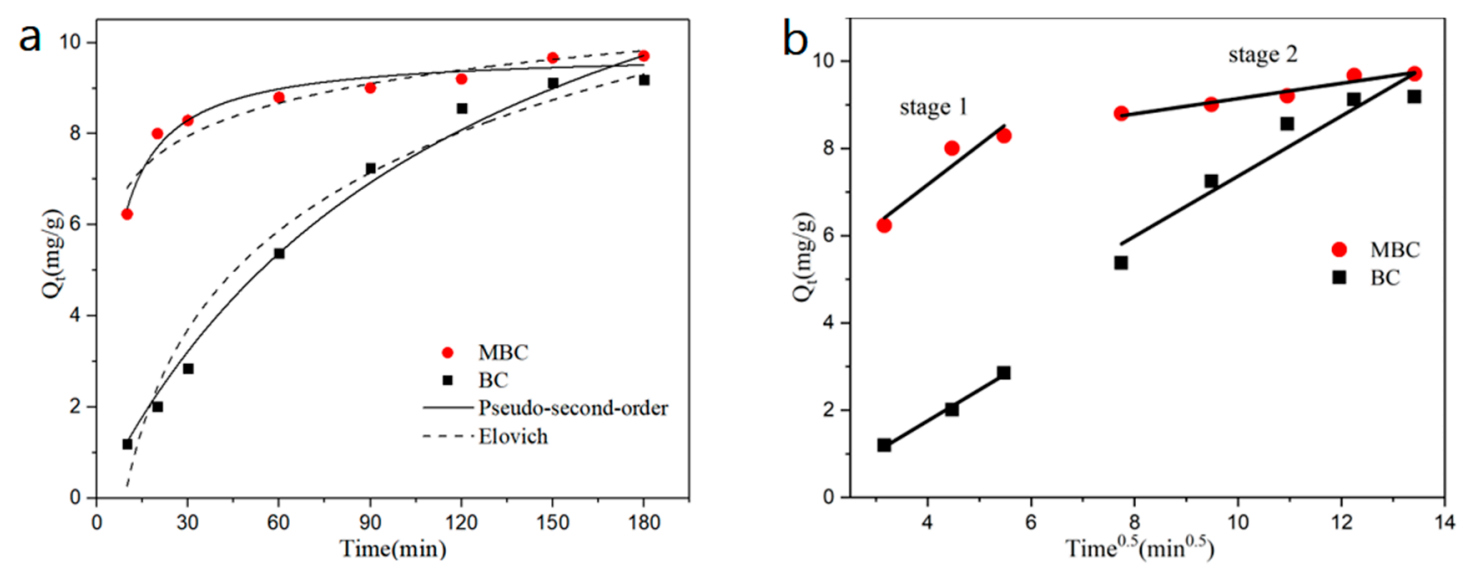

Figure 4. Effects of the adsorption equilibrium time on BPA adsorption and kinetic equation fitting: pseudo-second-order (P-S-O) and Elovich (a); intraparticle diffusion (b).

From the fitting results, it can be seen that the pseudo-second-order kinetic model has the best fitting effect on the adsorption of bisphenol $\mathrm{A}$ by $\mathrm{BC}$ and $\mathrm{MBC}$, and the correlation coefficient is above 0.98 , indicating that chemical adsorption is the rate control step of the adsorption process, and the adsorption mechanism is controlled by a variety of forces (such as $\pi-\pi$ electron donor-acceptor interaction, $\mathrm{H}$-bond, etc.). The Elovich model is commonly used to describe the adsorption behavior of adsorbents on non-uniform solid surfaces, while revealing data irregularity that is ignored by other dynamic models [47]. The correlation coefficient of BC and MBC fitted by the Elovich model is above 0.90 , indicating that the adsorption of $\mathrm{BC}$ and $\mathrm{MBC}$ to bisphenol $\mathrm{A}$ is a chemical adsorption process of 
a non-uniform solid adsorbent, with evenly distributed surface adsorption energy [48]. The analytical constant $\mathrm{b}$ of bisphenol $\mathrm{A}$ adsorption by $\mathrm{MBC}$ is smaller than that of $\mathrm{BC}$, indicating that the adsorption of bisphenol $\mathrm{A}$ by $\mathrm{MBC}$ is more stable [49]. In this experiment, the intraparticle diffusion model of bisphenol A by BC and MBC was fitted into two stages. The first stage is the diffusion of BPA through the liquid membrane to the surface of the adsorbent. The second stage is the adsorption of BPA on the surface of the adsorbent. The fitting effect of the first stage of MBC was poor (0.8045), the fitting effect of the second stage was good (0.9289), and the effect of BC was opposite. This indicated that magnetic modification affected the adsorption of bisphenol $\mathrm{A}$ by $\mathrm{MBC}$, accelerated the adsorption rate of bisphenol A, and reduced the adsorption resistance of bisphenol A [50]. The fitting parameters of the intraparticle diffusion model of $\mathrm{BC}$ and $\mathrm{MBC}$ are $k_{d 1}<k_{d 2}$ and $\mathrm{I}_{1}<\mathrm{I}_{2}$, indicating that the adsorption rate gradually decreases while the adsorption resistance gradually increases during the adsorption process [51]. At the same time, it can be seen from Figure $4 \mathrm{~b}$ that the fitted curves have not passed through the origin, indicating that the diffusion in particles is not the only rate control step, and the adsorption rate is also affected by chemical forces, such as ion exchange and H-bond [52].

Table 4. Fitting parameters of four kinetic models for adsorption of BPA onto BC and MBC.

\begin{tabular}{cccc}
\hline Kinetic Model & Parameters & BC & MBC \\
\hline Pseudo-first- & $k_{1} / \mathrm{min}^{-1}$ & 0.0114 & 0.0917 \\
order kinetic & $Q_{e} / \mathrm{mg}^{-1} \mathrm{~g}^{-1}$ & 10.9917 & 9.5010 \\
& $\mathrm{R}^{2}$ & 0.9922 & 0.9066 \\
Pseudo-second- & $k_{2} / \mathrm{g} \cdot(\mathrm{mg} \cdot \mathrm{min})^{-1}$ & 0.0005 & 0.0155 \\
order kinetic & $Q_{e} / \mathrm{mg}^{-1}$ & 16.2909 & 10.1574 \\
& $\mathrm{R}^{2}$ & 0.9870 & 0.9877 \\
Elovich & $a / \mathrm{mg} \cdot(\mathrm{g} \cdot \mathrm{min})^{-1}$ & -6.9359 & 4.0059 \\
& $b / \mathrm{g} \cdot \mathrm{mg}^{-1}$ & 3.1293 & 1.1806 \\
& $\mathrm{R}^{2}$ & 0.9625 & 0.9065 \\
Intraparticle diffusion & & & \\
& $k_{d 1} / \mathrm{mg} \cdot\left(\mathrm{mg} \cdot \mathrm{min}^{1 / 2}\right)^{-1}$ & 0.7115 & 0.9109 \\
Stage 1 & $\mathrm{I}_{1}$ & -1.0899 & 3.5282 \\
& $\mathrm{R}^{2}$ & 0.9857 & 0.8045 \\
Stage 2 & $\mathrm{I}_{2}$ & 0.6894 & 0.1749 \\
& $\mathrm{R}^{2}$ & 0.4711 & 7.3938 \\
& & 0.8883 & 0.9289 \\
\hline
\end{tabular}

\subsection{Effects of Initial BPA Concentration and Temperature}

The effect of initial BPA concentration on the adsorption of bisphenol A by BC and $\mathrm{MBC}$ is shown in Figure 5. With the increase of initial BPA concentration, the adsorption capacity of BC and MBC to bisphenol A also increased gradually. This is because the increased concentration of bisphenol A can enhance the adsorption drive between the adsorbent and the solute [53,54]. Four common adsorption isothermal models are used to further study the adsorption behavior and mechanism. The fitting results are shown in Figure 5, and the relevant fitting parameters are shown in Table 5; Table 6. 


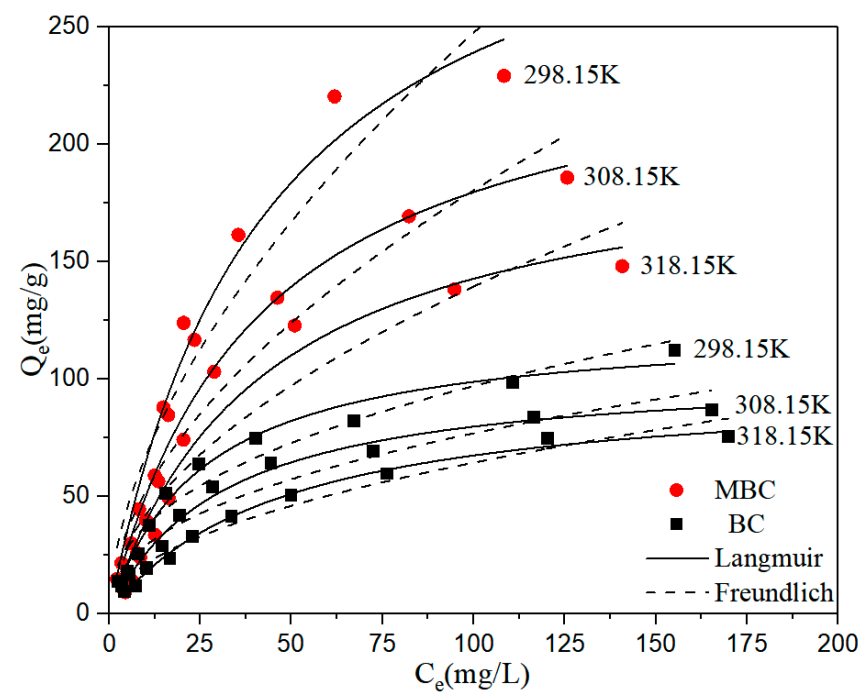

Figure 5. Adsorption isotherm fitting of BPA by BC and MBC.

Table 5. Fitting parameters of isotherm fitting for BPA adsorption onto BC.

\begin{tabular}{ccccc}
\hline Isotherm Models & Parameters & $\mathbf{2 9 8 . 1 5} \mathbf{K}$ & $\mathbf{3 0 8 . 1 5} \mathbf{K}$ & $\mathbf{3 1 8 . 1 5} \mathbf{K}$ \\
\hline Langmuir & $K_{L}\left(\mathrm{~L} \cdot \mathrm{mg}^{-1}\right)$ & 0.0394 & 0.0324 & 0.0213 \\
& $Q_{m}\left(\mathrm{mg}^{-1}\right)^{-1}$ & 123.8331 & 104.2741 & 99.0099 \\
& $\mathrm{R}^{2}$ & 0.9840 & 0.9830 & 0.9938 \\
Freundlich & $K_{F}\left(\mathrm{~L} \cdot \mathrm{mg}^{-1}\right)$ & 14.2885 & 10.8794 & 6.8863 \\
& $1 / \mathrm{n}$ & 0.4159 & 0.4244 & 0.4851 \\
& $\mathrm{R}^{2}$ & 0.9542 & 0.9286 & 0.9596 \\
Temkim & $\mathrm{A}$ & 24.7169 & 21.1330 & 19.7639 \\
& $K_{T}(\mathrm{mg} / \mathrm{L})$ & 0.4937 & 0.3899 & 0.2697 \\
& $\mathrm{R}^{2}$ & 0.9755 & 0.9626 & 0.9713 \\
D-R & $Q_{m} / \mathrm{mg}^{-1} \mathrm{~g}^{-1}$ & 92.0233 & 78.4427 & 67.6033 \\
& $\mathrm{E} / \mathrm{kJ} \cdot \mathrm{mol}^{-1}$ & 159.5204 & 121.9018 & 100.8157 \\
& $\mathrm{R}^{2}$ & 0.8496 & 0.8812 & 0.8318 \\
\hline
\end{tabular}

Table 6. Fitting parameters of isotherm fitting for BPA adsorption onto MBC.

\begin{tabular}{ccccc}
\hline Isotherm Models & Parameters & $\mathbf{2 9 8 . 1 5} \mathbf{K}$ & $\mathbf{3 0 8 . 1 5} \mathbf{K}$ & $\mathbf{3 1 8 . 1 5 K}$ \\
\hline Langmuir & $K_{L}\left(\mathrm{~L} \cdot \mathrm{mg}^{-1}\right)$ & 0.0232 & 0.0246 & 0.0238 \\
& $Q_{m}\left(\mathrm{mg}^{-1}\right)$ & 342.4692 & 252.5538 & 202.7956 \\
& $\mathrm{R}^{2}$ & 0.9724 & 0.9552 & 0.9416 \\
Freundlich & $K_{F}\left({\left.\mathrm{~L} \cdot \mathrm{mg}^{-1}\right)}\right.$ & 18.1606 & 14.9137 & 12.7045 \\
& $1 / \mathrm{n}^{2}$ & 0.5674 & 0.5413 & 0.5201 \\
Temkim & $\mathrm{R}^{2}$ & 0.9155 & 0.8924 & 0.8576 \\
& $\mathrm{~A}$ & 62.7503 & 55.4817 & 45.5962 \\
& $K_{T}(\mathrm{mg} / \mathrm{L})$ & 0.3427 & 0.2484 & 0.2246 \\
& $\mathrm{R}^{2}$ & 0.9219 & 0.9730 & 0.9555 \\
& $Q_{m} / \mathrm{mg}^{-1} \mathrm{~g}^{-1}$ & 219.6894 & 169.1809 & 141.9508 \\
& $\mathrm{E} / \mathrm{kJ} \cdot \mathrm{mol}^{-1}$ & 119.1388 & 131.5717 & 114.5335 \\
& $\mathrm{R}^{2}$ & 0.9325 & 0.9540 & 0.9667 \\
\hline
\end{tabular}

The Langmuir model best describes the adsorption isotherm of bisphenol A adsorbed by BC and $\mathrm{MBC}$, and the correlation coefficient is above 0.95. The Freundlich fit is also good. This indicates that bisphenol A has not only monolayer adsorption on BC and $\mathrm{MBC}$, but also multi-molecular adsorption. It is speculated that the reason may be that the load of $\gamma-\mathrm{Fe}_{2} \mathrm{O}_{3}$ on the surface of $\mathrm{BC}$ causes the surface of MBC to be rougher; thus, multi-molecular layer adsorption occurs locally. In addition, the 1/n of 
the Freundlich model represented the uniformity of the material surface, while the $1 / \mathrm{n}$ value of MBC fitting was greater than $\mathrm{BC}$, confirming this view. The A value in the Temkim equation represents the adsorbent coverage, while the A value of the BC adsorbed BPA fitting is smaller than that of the MBC fitting, indicating that the theoretical adsorbent coverage of BPA on BC is higher than that of MBC, that is, the electrostatic attraction between BC and BPA is stronger than MBC [55]. The parameter $\mathrm{E}$ of the D-R model is the characteristic energy. When $\mathrm{E}<16 \mathrm{~kJ} \cdot \mathrm{mol}^{-1}$, the adsorption was mainly physical adsorption. When $\mathrm{E}>40 \mathrm{~kJ} \cdot \mathrm{mol}^{-1}$, the adsorption was mainly chemical adsorption. The fitted $\mathrm{E}$ values were $>40 \mathrm{~kJ} \cdot \mathrm{mol}^{-1}$, indicating that the adsorption process was dominated by chemical adsorption. By calculating the equilibrium parameter $\mathrm{R}_{L}$, we can judge whether the adsorption process is favorable [56]. ( $0<R_{L}<1$ is a favorable adsorption. $R_{L}>1$ is an unfavorable adsorption. $R_{L}=1$ is a linear adsorption. $R_{L}=0$ is a irreversible adsorption.) The calculation formula is as follows, and the meanings of parameters are the same as above:

$$
\mathrm{R}_{L}=\frac{1}{1+K_{L} C_{0}} .
$$

The calculation shows that the $\mathrm{R}_{L}$ values of $\mathrm{BC}$ and $\mathrm{MBC}$ are within the range of $0 \sim 1$. Therefore, the adsorption of bisphenol $\mathrm{A}$ by $\mathrm{BC}$ and $\mathrm{MBC}$ is favorable.

The effect of temperature on the adsorption of bisphenol A by BC and MBC is shown in Figure 5. With the increase of temperature, the adsorption capacity of bisphenol A by BC and MBC decreased. In order to further explore the thermodynamics of adsorption of bisphenol A by BC and MBC, Equations (12) and (13) are used to calculate the adsorption data at different temperatures to calculate the gibbs free energy $(\Delta \mathrm{G})$, enthalpy $(\Delta \mathrm{H})$, and entropy $(\Delta \mathrm{S})$ in the adsorption process. The calculation formula is as follows:

$$
\begin{gathered}
\Delta \mathrm{G}=-\mathrm{RT}_{\ln \mathrm{K}_{e},} \\
\Delta \mathrm{G}=\Delta \mathrm{H}-\mathrm{T} \Delta \mathrm{S},
\end{gathered}
$$

where $\mathrm{R}$ is the gas constant, $8.314 \mathrm{~J} \cdot(\mathrm{mol} \cdot \mathrm{K})^{-1}$. T is temperature, $\mathrm{K} . \ln \mathrm{K}_{e}$ is the equilibrium constant. The results are listed in Table 7 . The $\Delta \mathrm{H}$ values are negative, indicating that the $\mathrm{BC}$ and $\mathrm{MBC}$ adsorption process of bisphenol $\mathrm{A}$ is exothermic. It is generally believed that when $\Delta \mathrm{H}$ values are within the range of 2.1-20.9 $\mathrm{kJ} \cdot \mathrm{mol}^{-1}$, the adsorption process is mainly dominated by physical adsorption [57]. While $\Delta \mathrm{H}$ values are not in the range of this study, the BC and MBC adsorption process of bisphenol $\mathrm{A}$ is mainly dominated by chemical adsorption. $\Delta \mathrm{G}$ is less than 0 and decreases with the decrease of temperature, indicating that the $\mathrm{BC}$ and $\mathrm{MBC}$ adsorption reaction of bisphenol $\mathrm{A}$ is a spontaneous exothermic reaction. $\triangle S<0$ reveals a decrease in the disorder between the adsorbent and the solute during the adsorption of BPA by BC and MBC [58].

Table 7. Thermodynamic parameters of BPA adsorption onto BC and MBC at various temperatures.

\begin{tabular}{cccccc}
\hline & $\mathbf{T} / \mathbf{K}$ & $\mathbf{l n} \mathbf{K}_{\mathbf{e}}$ & $\Delta \mathbf{G} / \mathbf{k J} \cdot \mathbf{m o l}^{-\mathbf{1}}$ & $\Delta \mathbf{H} / \mathbf{k J} \cdot \mathbf{m o l}^{-\mathbf{1}}$ & $\Delta \mathbf{S} / \mathbf{J}(\mathbf{m o l} \cdot \mathbf{K})^{-\mathbf{1}}$ \\
\hline \multirow{3}{*}{$\mathbf{B C}$} & 298.15 & 1.3541 & -3.3566 & & \\
& 308.15 & 0.9884 & -2.5322 & -29.6316 & -88.0668 \\
& 318.15 & 0.6021 & -1.5926 & & \\
$\mathbf{F e}_{2} \mathbf{O}_{\mathbf{3}} @ \mathbf{B C}$ & 298.15 & 1.8341 & -4.5464 & & \\
& 308.15 & 1.3939 & -3.5711 & -28.6981 & -81.1800 \\
& 318.15 & 1.1078 & -2.9302 & & \\
\hline
\end{tabular}

\subsection{Effects of Solution $\mathrm{pH}$ and Ionic Strength}

Figure 6a shows the effect of solution $\mathrm{pH}$ on the adsorption of bisphenol A by BC and MBC. As can be seen from the figure, the adsorption of bisphenol $\mathrm{A}$ by $\mathrm{BC}$ and $\mathrm{MBC}$ is strongly $\mathrm{pH}$ dependent. The maximum adsorption capacity of $\mathrm{BC}$ to bisphenol $\mathrm{A}$ occurs at $\mathrm{pH}=3$, which is due to the formation of $\pi-\pi$ electron donor-acceptor interaction (EDA) between BC and bisphenol A, accompanied by a 
strong H-bond [59,60]. When $\mathrm{pH}$ increased from 6 to 7 , the adsorption capacity of $\mathrm{BC}$ to bisphenol $\mathrm{A}$ rose again. This is because bisphenol A begins to partially dissociate, and bisphenol $\mathrm{A}$ in the solution is no longer in molecular form, but part of $\mathrm{HBPA}^{-}$appears. The surface of $\mathrm{BC}$ is positively charged, and the electrostatic attraction between $\mathrm{BC}$ and $\mathrm{HBPA}^{-}$enhances the adsorption. The subsequent increase in $\mathrm{pH}$ resulted in a further decrease in the adsorption capacity of $\mathrm{BC}$ to bisphenol A. This is because the $\pi-\pi$ electron donor-acceptor interaction (EDA) and hydrogen bonding between $\mathrm{BC}$ and BPA is weakened when the $\mathrm{pH}$ of the solution is greater than the acid dissociation constant of BPA [61]. The adsorption capacity of bisphenol A by MBC increased at first and then decreased with the increase of $\mathrm{pH}$, and the maximum adsorption capacity occurred at $\mathrm{pH}=6$. The zero point charge of $\mathrm{MBC}, \mathrm{pH}_{\mathrm{pzc}}$, is 5.86. When the $\mathrm{pH}$ is less than 6, the dissociation of BPA increases with the increase of $\mathrm{pH}$. The increase in $\mathrm{HBPA}^{-}$leads to increased electrostatic attraction between BPA and positively charged MBC surfaces. In addition, protonated phenol -OH on BPA under acidic conditions will also generate electrostatic repulsion with $\mathrm{MBC}$, which is not conducive to the adsorption of BPA by MBC. When the $\mathrm{pH}$ continues to rise, BPA further dissociates to produce the more electronegative $\mathrm{BPA}^{2-}$, which generates a strong electrostatic repulsion with the negatively charged MBC surface, resulting in a decrease in the adsorption capacity.
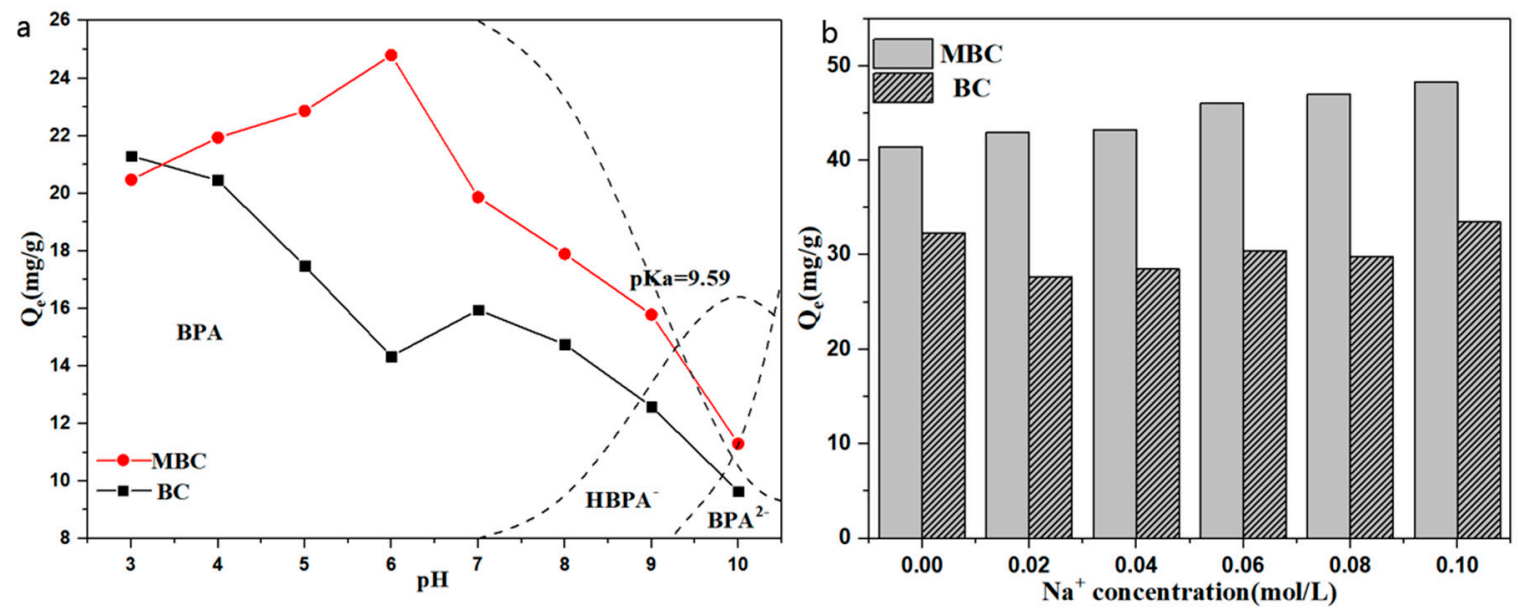

Figure 6. Effects of $\mathrm{pH}(\mathbf{a})$ and $\mathrm{Na}^{+}$concentration $(\mathbf{b})$ on the adsorption of BPA by BC and MBC.

As shown in Figure $6 \mathrm{~b}$, with the increase of $\mathrm{NaCl}$ concentration, the adsorption capacity of $\mathrm{BC}$ to BPA decreased at first and then increased. When the $\mathrm{Na}^{+}$concentration was $0.10 \mathrm{~mol} \cdot \mathrm{L}^{-1}$, the adsorption capacity was almost the same as when $\mathrm{NaCl}$ was not added. However, the increase of $\mathrm{Na}^{+}$ concentration significantly enhanced the adsorption capacity of BPA to MBC. The addition of $\mathrm{NaCl}$ not only makes BPA exist in more molecular states (salting out effect), but also deeply penetrates into the diffusion layer on the adsorbent surface, weakens the repulsive effect between adsorbents, and makes the adsorbents more compact (squeezing out effect). Among them, the "salting out effect" will enhance the hydrophobic effect between BC, MBC, and BPA to enhance the adsorption effect, while the "squeezing out effect" will reduce the effective adsorption area of the adsorbent and weaken the adsorption of $\mathrm{BC}$ and $\mathrm{MBC}$ to $\mathrm{BPA}$. Therefore, the $\mathrm{Na}^{+}$concentration is in the range of $0-0.10 \mathrm{~mol} \cdot \mathrm{L}^{-1}$, and the two effects combined show that the adsorption capacity of BC adsorbed BPA is inhibited first and then recovered. However, the specific surface area of $\mathrm{MBC}\left(20.732 \mathrm{~m}^{2} \cdot \mathrm{g}^{-1}\right)$ is much higher than that of $\mathrm{BC}\left(1.706 \mathrm{~m}^{2} \cdot \mathrm{g}^{-1}\right)$, and the "squeezing out effect" has little influence on $\mathrm{MBC}$, so it is shown as a promotion effect.

\subsection{Mechanism of the Adsorption of BPA by $B C$ and $M B C$}

Figure 7 is a schematic diagram of the mechanism of the adsorption of BPA by BC and MBC. The average pore size of $\mathrm{BC}$ and $\mathrm{MBC}$ is between 2 and $50 \mathrm{~nm}$, which is mesoporous. BPA molecules can 
enter the pores of $\mathrm{BC}$ and $\mathrm{MBC}$ through pore filling. As mentioned above, the adsorption capacity of $\mathrm{BC}$ and MBC to BPA is greatly affected by $\mathrm{pH}$. Under acidic conditions, the phenolic hydroxyl groups in the structure of BPA protonize, generating electrostatic repulsion with the positively charged surfaces of $\mathrm{BC}$ and $\mathrm{MBC}$. The functional group -OH on the surface of $\mathrm{BC}$ and $\mathrm{MBC}$ also forms strong hydrogen bonds with the $-\mathrm{OH}$ and $\mathrm{C}-\mathrm{H}$ on the molecular structure of BPA. In addition, acidic functional groups of $\mathrm{BC}$ and $\mathrm{MBC}$ (such as $-\mathrm{COOH}, \mathrm{C}=\mathrm{O}$, etc.) can act as electron acceptors, forming $\pi-\pi$ electron donor-acceptor interactions (EDA) with BPA.

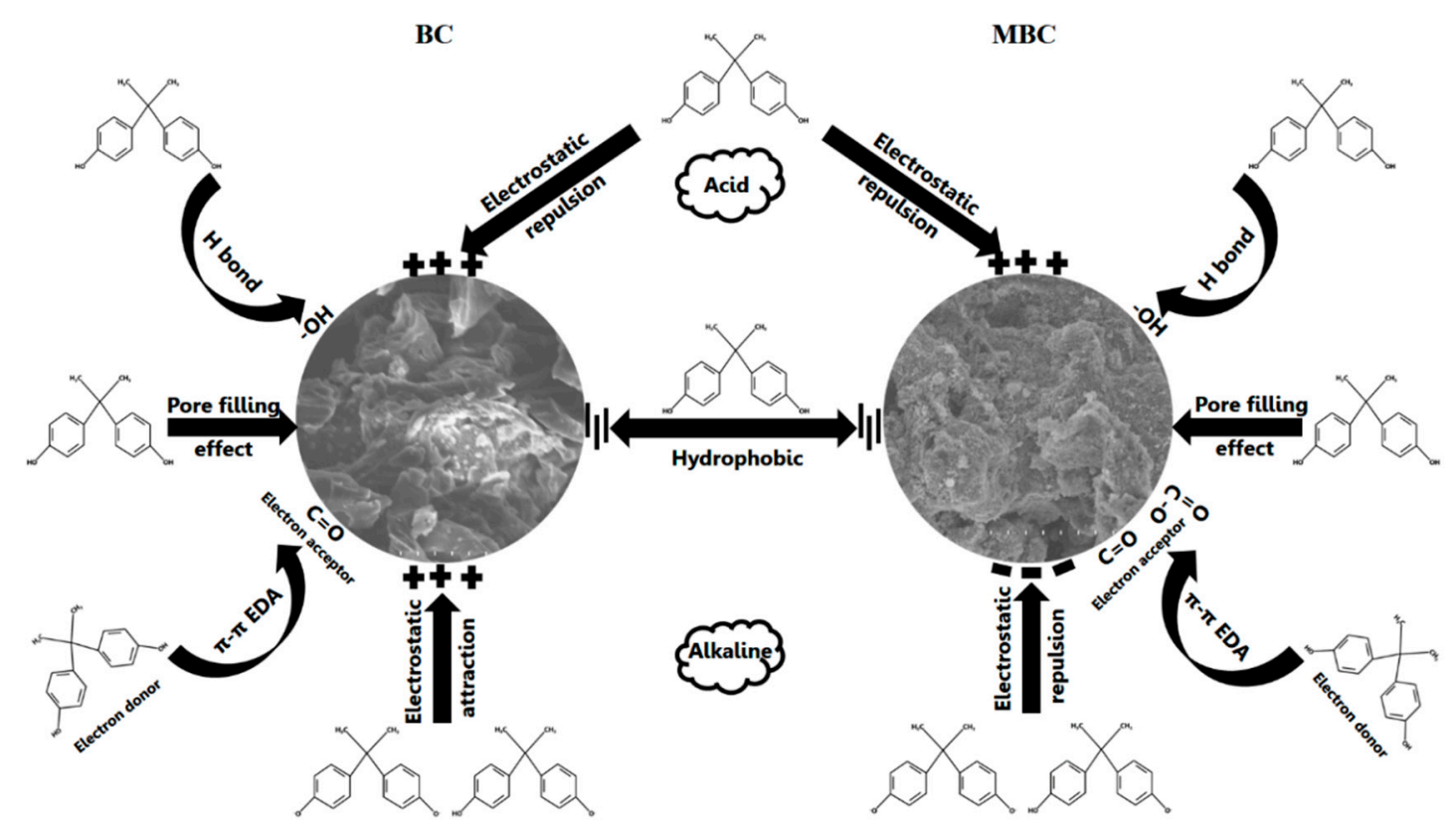

Figure 7. Mechanism of adsorption of BPA by BC and MBC.

Under alkaline conditions, the surface of $\mathrm{MBC}$ is converted into a negative charge, which maintains electrostatic repulsion with the dissociated $\mathrm{HBPA}^{-}$and $\mathrm{BPA}^{2-}$, while $\mathrm{BC}$ is the opposite. In addition, the hydrogen bonds between $\mathrm{BC}, \mathrm{MBC}$, and $\mathrm{BPA}$, as well as the $\pi-\pi$ electron donor-acceptor interaction (EDA), would be greatly weakened, making it difficult for BC and MBC to absorb bisphenol A. Bisphenol A has strong hydrophobicity and can be combined with the hydrophobic site on the surface of $\mathrm{BC}$ and $\mathrm{MBC}$. Therefore, a hydrophobic interaction is also an important driving force for BC and MBC to absorb BPA.

\section{Conclusions}

In this paper, grapefruit peel waste was used as a biochar source to prepare biochar and magnetize it. Through characterization, the modified magnetic biochar was found to have a larger specific surface area, larger pore volume, and more oxygen-containing functional groups. The prepared magnetic biochar is loaded with nano $\gamma-\mathrm{Fe}_{2} \mathrm{O}_{3}$ particles, and thus possessing excellent magnetic separation ability. BC and MBC were used to adsorb BPA in simulated wastewater, and it was found that the adsorption kinetics and adsorption isotherm were in accordance with the pseudo-second-order kinetics model and Langmuir model, respectively. The adsorption of BPA by BC and MBC is a spontaneous exothermic reaction with strong $\mathrm{pH}$ and ionic strength dependence. The study of the adsorption mechanism shows that the $\mathrm{H}$-bond and the $\pi-\pi$ electron donor-acceptor interaction (EDA) are the main forces for BC and MBC to adsorb BPA. After cyclic adsorption of BPA for four times, the adsorption capacity of $\mathrm{MBC}$ to $\mathrm{BPA}$ can still reach about $80 \%$ of the initial adsorption capacity, with good recycling and reusability. 
Author Contributions: Writing—original draft, J.W.; writing—review \& editing, M.Z. All authors have read and agreed to the published version of the manuscript.

Funding: This research was supported by the National Natural Science Foundation of China $(51808001,51409001)$ and Natural science foundation of Anhui province (1808085QE146, 1808085ME133, 1708085QB45).

Conflicts of Interest: The authors have declared no conflict of interest.

\section{References}

1. Wu, C.X.; Huang, X.L.; Lin, J.; Liu, J.T. Occurrence and fate of selected endocrine-disrupting chemicals in water and sediment from an urban lake. Arch. Environ. Contam. Toxicol. 2015, 68, 225-236. [CrossRef] [PubMed]

2. Diamanti-Kandarakis, E.; Bourguignon, J.P.; Giudice, L.C.; Hauser, R.; Prins, G.S.; Soto, A.M.; Zoeller, R.T.; Gore, A.C. Endocrine-disrupting chemicals: An endocrine society scientific statement. Endocr. Rev. 2009, 30, 293-342. [CrossRef] [PubMed]

3. Zhao, J.L.; Ying, G.G.; Wang, L.; Yang, J.F.; Yang, X.B.; Yang, L.H.; Li, X. Determination of phenolic endocrine disrupting chemicals and acidic pharmaceuticals in surface water of the Pearl Rivers in South China by gas chromatography-negative chemical ionization-mass spectrometry. Sci. Total Environ. 2009, 407, 962-974. [CrossRef] [PubMed]

4. Jonkers, N.; Sousa, A.; Galante-Oliveira, S.; Barroso, C.M.; Kohler, H.P.E.; Giger, W. Occurrence and sources of selected phenolic endocrine disruptors in Ria de Aveiro, Portugal. Environ. Sci. Pollut. Res. 2010, 17, 834-843. [CrossRef] [PubMed]

5. Kang, J.H.; Asai, D.; Katayama, Y. Bisphenol A in the aquatic environment and its endocrine-disruptive effects on aquatic organisms. Crit. Rev. Toxicol. 2007, 37, 607-625. [CrossRef] [PubMed]

6. European Community. European Union Risk Assessment Report: 4,4'-Isopropylidenediphenol (Bisphenol-A); European Communities: Brussels, Belgium, 2010.

7. Saal, F.S.V.; Nagel, S.C.; Coe, B.L.; Angle, B.M.; Taylor, J.A. The estrogenic endocrine disrupting chemical bisphenol A (BPA) and obesity. Mol. Cell. Endocrinol. 2012, 354, 74-84. [CrossRef]

8. Crain, D.A.; Eriksen, M.; Iguchi, T.; Jobling, S.; Laufer, H.; LeBlanc, G.A.; Guillette, L.J.J. An ecological assessment of bisphenol-A: Evidence from comparative biology. Reprod. Toxicol. 2007, 24, 225-239. [CrossRef]

9. Wintgens, T.; Gallenkemper, M.; Melin, T. Occurrence and removal of endocrine disrupters in landfill leachate treatment plants. Water Sci. Technol. 2003, 48, 127-134. [CrossRef]

10. Cousins, I.T.; Staples, C.A.; Kleĉka, G.M.; Mackay, D. A Multimedia Assessment of the Environmental Fate of Bisphenol A. Hum. Ecol. Risk Assess. Int. J. 2010, 8, 1107-1135. [CrossRef]

11. Kang, J.H.; Kondo, F. Bisphenol A degradation by bacteria isolated from river water. Arch. Environ. Contam. Toxicol. 2002, 43, 265-269. [CrossRef]

12. Mohapatra, D.P.; Brar, S.K.; Tyagi, R.D.; Surampalli, R.Y. Physio-chemcial pretreatment and biotransformation of wastewater and wastewater sludge-fate of bisphenol A. Chemosphere 2010, 78, 923-941. [CrossRef] [PubMed]

13. Kolpin, D.W.; Furlong, E.T.; Meyer, M.T.; Thurman, E.M.; Zaugg, S.D.; Barber, L.B.; Buxton, H.T. Pharmaceuticals, hormones, and other organic wastewater contaminants in U.S. streams, 1999-2000: A national reconnaissance. Environ. Sci. Technol. 2002, 36, 1202-1211. [CrossRef] [PubMed]

14. Ahmed, M.B.; Zhou, J.L.; Ngo, H.H.; Guo, W.S.; Thomaidis, N.S.; Xu, J. Progress in the biological and chemical treatment technologies for emerging contaminant removal from wastewater: A critical review. J. Hazard. Mater. 2017, 323, 274-298. [CrossRef] [PubMed]

15. Zhang, L.; Fang, P.; Yang, L.J.; Zhang, J.; Wang, X. Rapid method for the separation and recovery of endocrine-disrupting compound bisphenol AP from wastewater. Langmuir 2013, 29, 3968-3975. [CrossRef] [PubMed]

16. Jiang, J.Q.; Yin, Q.; Zhou, J.L.; Pearce, P. Occurrence and treatment trials of endocrine disrupting chemicals (EDCs) in wastewaters. Chemosphere 2005, 61, 544-550. [CrossRef]

17. Esplugas, S.; Bila, D.M.; Krause, L.G.T.; Dezotti, M. Ozonation and advanced oxidation technologies to remove endocrine disrupting chemicals (EDCs) and pharmaceuticals and personal care products (PPCPs) in water effluents. J. Hazard. Mater. 2007, 149, 631-642. [CrossRef]

18. Zhang, A.; Wang, J.; Li, Y.M. Performance of calcium peroxide for removal of endocrine disrupting compounds in waste activated sludge and promotion of sludge solubilization. Water Res. 2015, 71, 125-139. [CrossRef] 
19. Grover, D.P.; Zhou, J.L.; Frickers, P.E.; Readman, J.W. Improved removal of estrogenic and pharmaceutical compounds in sewage effluent by full scale granular activated carbon: Impact on receiving river water. J. Hazard. Mater. 2011, 185, 1005-1011. [CrossRef]

20. Jung, C.; Park, J.; Lim, K.H.; Park, S.; Heo, J.; Her, N.; Oh, J.; Yun, S.; Yoon, Y. Adsorption of selected endocrine disrupting compounds and pharmaceuticals on activated biochars. J. Hazard. Mater. 2013, 263, 702-710. [CrossRef]

21. Redding, A.M.; Cannon, F.S.; Snyder, S.A.; Vanderford, B.J. A QSAR-like analysis of the adsorption of endocrine disrupting compounds, pharmaceuticals, and personal care products on modified activated carbons. Water Res. 2009, 43, 3849-3861. [CrossRef]

22. Yu, Z.; Peldszus, S.; Huck, P.M. Adsorption characteristics of selected pharmaceuticals and an endocrine disrupting compound-Naproxen, carbamazepine and nonylphenol-On activated carbon. Water Res. 2008, 42, 2873-2882. [CrossRef] [PubMed]

23. Zhang, C.; Lai, C.; Zeng, G.M.; Huang, D.L.; Yang, C.P.; Wang, Y.; Zhou, Y.Y.; Cheng, M. Efficacy of carbonaceous nanocomposites for sorbing ionizable antibiotic sulfamethazine from aqueous solution. Water Res. 2016, 95, 103-112. [CrossRef] [PubMed]

24. Pan, B.; Lin, D.; Mashayekhi, H.; Xing, B. Adsorption and Hysteresis of Bisphenol A and $17 \alpha$-Ethinyl Estradiol on Carbon Nanomaterials. Environm. Sci. Technol. 2008, 42, 5480-5485. [CrossRef] [PubMed]

25. Zhang, L.; Pan, F.; Liu, X.Y.; Yang, L.J.; Jiang, X.Q.; Yang, J.C.; Shi, W. Multi-walled carbon nanotubes as sorbent for recovery of endocrine disrupting compound-bisphenol F from wastewater. Chem. Eng. J. 2013, 218, 238-246. [CrossRef]

26. Jung, C.; Boateng, L.K.; Flora, J.R.V.; Oh, J.; Braswell, M.C.; Son, A.; Yoon, Y. Competitive adsorption of selected non-steroidal anti-inflammatory drugs on activated biochars: Experimental and molecular modeling study. Chem. Eng. J. 2015, 264, 1-9. [CrossRef]

27. Ahmed, M.B.; Zhou, J.L.; Ngo, H.H.; Guo, W.S.; Chen, M.F. Progress in the preparation and application of modified biochar for improved contaminant removal from water and wastewater. Bioresour. Technol. 2016, 214, 836-851. [CrossRef] [PubMed]

28. Ahmed, M.B.; Zhou, J.L.; Ngo, H.H.; Guo, W.S. Insight into biochar properties and its cost analysis. Biomass Bioenergy 2016, 84, 76-86. [CrossRef]

29. Ahmed, M.B.; Zhou, J.L.; Ngo, H.H.; Guo, W.S. Adsorptive removal of antibiotics from water and wastewater: Progress and challenges. Sci. Total Environ. 2015, 532, 112-126. [CrossRef]

30. Wang, S.S.; Gao, B.; Zimmerman, A.R.; Li, Y.C.; Ma, L.; Harris, W.G.; Migliaccio, K.W. Removal of arsenic by magnetic biochar prepared from pinewood and natural hematite. Bioresour. Technol. 2014, 175, 391-395. [CrossRef]

31. Jiang, S.F.; Xi, K.F.; Yang, J.; Jiang, H. Biochar-supported magnetic noble metallic nanoparticles for the fast recovery of excessive reductant during pollutant reduction. Chemosphere 2019, 227, 63-71. [CrossRef]

32. Methacanon, P.; Krongsin, J.; Gamonpilas, C. Pomelo (Citrus maxima) pectin: Effects of extraction parameters and its properties. Food Hydrocoll. 2014, 35, 383-391. [CrossRef]

33. Zhang, G.Y.; Sun, Y.; Guo, Y.L.; Liu, J.H.; Wu, L.Y.; Lin, J.K. The application of pomelo peel as a carrier for adsorption of epigallocatechin-3-gallate. J. Sci. Food Agric. 2018, 98, 4135-4141. [CrossRef] [PubMed]

34. Bastami, T.R.; Entezari, M.H. Activated carbon from carrot dross combined with magnetite nanoparticles for the efficient removal of p-nitrophenol from aqueous solution. Chem. Eng. J. 2012, 210, 510-519. [CrossRef]

35. Xie, J.; Wang, Z.; Wu, D.Y.; Li, C.J. Adsorption of phenol chemicals by surfactant-modified zeolites. Huanjing kexue 2012, 33, 4361-4366.

36. Berhane, T.M.; Levy, J.; Krekeler, M.P.S.; Danielson, N.D. Adsorption of bisphenol A and ciprofloxacin by palygorskite-montmorillonite: Effect of granule size, solution chemistry and temperature. Appl. Clay Sci. 2016, 132, 518-527. [CrossRef]

37. Rong, X.; Xie, M.; Kong, L.S.; Natarajan, V.; Ma, L.; Zhan, J.H. The magnetic biochar derived from banana peels as a persulfate activator for organic contaminants degradation. Chem. Eng. J. 2019, 372, 294-303. [CrossRef]

38. Wang, R.Z.; Huang, D.L.; Liu, Y.G.; Peng, Z.W.; Zeng, G.M.; Lai, C.; Xu, P.; Huang, C.; Zhang, C.; Gong, X.M. Selective removal of BPA from aqueous solution using molecularly imprinted polymers based on magnetic graphene oxide. Rsc Adv. 2016, 6, 106201-106210. [CrossRef] 
39. Yu, T.; Peng, M.L.; Yang, J.C.; Huang, X.; Long, S.R.; Zhang, G.; Wang, X.J.; Yang, J. PES magnetic microspheres: Preparation and performance for the removal of endocrine disruptor-BPA. Rsc Adv. 2017, 7, 52729-52737. [CrossRef]

40. Osman, B.; Ozer, E.T.; Kara, A.; Yesilova, E.; Besirli, N. Properties of magnetic microbeads in removing bisphenol-A from aqueous phase. J. Porous Mater. 2015, 22, 37-46. [CrossRef]

41. Heo, J.; Yoon, Y.; Lee, G.; Kim, Y.; Han, J.; Park, C.M. Enhanced adsorption of bisphenol A and sulfamethoxazole by a novel magnetic CuZnFe2O4-biochar composite. Bioresour. Technol. 2019, 281, 179-187. [CrossRef]

42. Yang, X.J.; Zhan, J.Y.; Yu, J.; Liu, G.; Huang, R.X. Adsorption features and kinetics of bisphenol A onto magnetic composite organic sepiolite. Chin. J. Environ. Eng. 2016, 10, 3597-3602.

43. Datsyuk, V.; Kalyva, M.; Papagelis, K.; Parthenios, J.; Tasis, D.; Siokou, A. Chemical oxidation of multiwalled carbon nanotubes. Carbon 2008, 46, 833-840. [CrossRef]

44. Hu, P.D.; Su, H.R.; Chen, Z.Y.; Yu, C.Y.; Li, Q.L.; Zhou, B.X.; Alvarez, P.J.J.; Long, M.C. Selective degradation of organic pollutants using an efficient metal-free catalyst derived from carbonized polypyrrole via peroxymonosulfate activation. Environ. Sci. Technol. 2017, 51, 11288-11296. [CrossRef] [PubMed]

45. Garg, V.K.; Gupta, R.; Bala Yadav, A.; Kumar, R. Dye removal from aqueous solution by adsorption on treated sawdust. Bioresour. Technol. 2003, 89, 121-124. [CrossRef]

46. Namasivayam, C.; Prabha, D.; Kumutha, M. Removal of direct red and acid brilliant blue by adsorption on to banana pith. Bioresour. Technol. 1998, 64, 77-79. [CrossRef]

47. Arris, S.; Lehocine, M.B.; Meniai, A.H. Sorption study of chromium sorption from wastewater using cereal by-products. Int. J. Hydrog. Energy 2016, 41, 10299-10310. [CrossRef]

48. Wang, T.T.; Cui, Q.L.; Wang, L.L.; Tan, L.S.; Sun, C.C.; Zhen, J.Y. Adsorption characteristics and mechanism of phosphate from aqueous solutions on $\mathrm{Al}$ modification biochar produced from Caragana Korshinskii. China Environ. Sci. 2018, 38, 2210-2222. [CrossRef]

49. Wang, H.Y.; Gao, B.; Wang, S.S.; Fang, J.; Xue, Y.W.; Yang, K. Removal of Pb(II), Cu(II), and Cd(II) from aqueous solutions by biochar derived from KMnO4 treated hickory wood. Bioresour. Technol. 2015, 197, 356-362. [CrossRef]

50. Xu, D.Y.; Zhang, M.; Yang, W.W.; Liu, T.T.; Yao, Q.F.; Hong, Y.J. Preparation of alumina modified sludge biocharcoal particles and their adsorption characteristics for $\mathrm{Pb}(\mathrm{II})$. Chem. Ind. Eng. Prog. 2019. [CrossRef]

51. Yang, K.; Jiang, Y.; Yang, J.J.; Lin, D.H. Correlations and adsorption mechanisms of aromatic compounds on biochars produced from various biomass at $700{ }^{\circ} \mathrm{C}$. Environ. Pollut. 2018, 233, 64-70. [CrossRef]

52. Ma, F.F.; Zhao, B.W.; Diao, J.R. Adsorptive characteristics of cadmium onto biochar produced from pyrolysis of wheat straw in aqueous solution. China Environ. Sci. 2017, 37, 551-559.

53. Idrees, M.; Batool, S.; Kalsoom, T.; Yasmeen, S.; Kalsoom, A.; Raina, S.; Zhuang, Q.; Kong, J. Animal manure-derived biochars produced via fast pyrolysis for the removal of divalent copper from aqueous media. J. Environ. Manag. 2018, 213, 109-118. [CrossRef] [PubMed]

54. Lee, C.G.; Park, J.A.; Choi, J.W.; Ko, S.O.; Lee, S.H. Removal and recovery of Cr(VI) from industrial plating wastewater using fibrous anion exchanger. Water Air Soil Pollut. 2016, 227, 287. [CrossRef]

55. Wu, H.W.; Chen, M.; Huang, X.J.; Su, Z.J.; Sun, T.L.; Tan, X.Y.; Feng, Q.Y. Preparation of modified biochar for adsorption of cefotaxime in solution. China Environ. Sci. 2018, 38, 2527-2534. [CrossRef]

56. Baig, S.A.; Zhu, J.; Muhammad, N.; Sheng, T.T.; Xu, X.H. Effect of synthesis methods on magnetic Kans grass biochar for enhanced As(III, V) adsorption from aqueous solutions. Biomass Bioenergy 2014, 71, $299-310$. [CrossRef]

57. Arampatzidou, A.C.; Deliyanni, E.A. Comparison of activation media and pyrolysis temperature for activated carbons development by pyrolysis of potato peels for effective adsorption of endocrine disruptor bisphenol-A. J. Colloid Interface Sci. 2016, 466, 101-112. [CrossRef]

58. Dong, X.W.; He, L.Z.; Hu, H.; Liu, N.; Gao, S.; Piao, Y.X. Removal of $17 \beta$-estradiol by using highly adsorptive magnetic biochar nanoparticles from aqueous solution. Chem. Eng. J. 2018. [CrossRef]

59. Ahmed, M.B.; Zhou, J.L.; Ngo, H.H.; Guo, W.S.; Johir, M.A.; Belhaj, D. Competitive sorption affinity of sulfonamides and chloramphenicol antibiotics toward functionalized biochar for water and wastewater treatment. Bioresour. Technol. 2017, 238, 306-312. [CrossRef] 
60. Ahmed, M.B.; Zhou, J.L.; Ngo, H.H.; Guo, W.S.; Johir, M.A.H.; Sornalingam, K.; Belhaj, D.; Kallel, M. Nano-Fe-0 immobilized onto functionalized biochar gaining excellent stability during sorption and reduction of chloramphenicol via transforming to reusable magnetic composite. Chem. Eng. J. 2017, 322, 571-581. [CrossRef]

61. Ahmed, M.B.; Zhou, J.L.; Ngo, H.H.; Johir, M.A.; Sornalingam, K. Sorptive removal of phenolic endocrine disruptors by functionalized biochar: Competitive interaction mechanism, removal efficacy and application in wastewater. Chem. Eng. J. 2018, 335, 801-811. [CrossRef]

(C) 2020 by the authors. Licensee MDPI, Basel, Switzerland. This article is an open access article distributed under the terms and conditions of the Creative Commons Attribution (CC BY) license (http://creativecommons.org/licenses/by/4.0/). 